\title{
Slovenian students on Projects/Internships
}

\author{
Tatjana Welzer Družovec ${ }^{\#, 1}$, Lili Nemec Zlatolas ${ }^{\#, 2}$, Nuno Escudeiro ${ }^{*, 3}$ \\ ${ }^{\#}$ University of Maribor, Faculty of Electrical Engineering and Computer Science \\ Smetanova 17, Maribor, Slovenia \\ ${ }^{1}$ tatjana.welzer@um.si \\ ${ }^{2}$ lili.nemeczlatolaseum.si \\ ${ }^{*}$ Inst. Sup. De Engenharia do Porto, Depart. De Eng. Informatica \\ R. Antonio Bernardino de Almeida, 431, 4200-072 Porto, Portugal \\ ${ }^{3}$ nfelisep.ipp.pt
}

\begin{abstract}
PRAXIS is the European Network aiming to setup the European Center for Project/Internship (IP) Excellence, which is developed for needs of project oriented education and between others also support internationalization at home and mobility of students abroad. Project/Internship course units are particularly relevant to engineering degrees. It is through this type of courses that students have the chance to practice their technical skills in a real-world-like setting and experience soft skills that are a key factor for employability. Besides students and teachers also companies and HEI (Higher Education Institution) are included and integrated into PRAXIS and new connections are possible. For needs of PRAXIS project, we did a PI survey in which students, HEI and companies where involved. We decided to have analysis for Slovenian student separately on the base number of completed questionnaires/partners ratio, which was the highest between all 31 participating countries.
\end{abstract}

Keywords - Students, Survey, Projects, Internships, Questionaire

\section{INTRODUCTION}

Research on Project/Internship questionnaire was conducted across 31 different European countries with the purpose of identifying the preferences of students with regards to their Project/Internship courses [1]. Questionnaire was completed by 1797 students. Among them 433 students from Spain from three Spanish partners and 288 students from Slovenia from the University of Maribor, Faculty of Electrical Engineering and Computer Science one of two Slovenian partners. We contribute most of questionnaires 278 out of 288 . So ratio on the base number of completed questionnaires/partners was the highest.

In the survey we included students from all three levels of studies - bachelors, masters and doctoral students. In the analysis we decided to take only bachelor students, which are mostly involved into Project/Internship courses, while master and doctoral students usually make a decision for Erasmus Internship.

The paper is presenting findings of the Slovenian part of the study as defined above.

\section{METHODOLOGY}

The survey was conducted online using the questionnaire. Students at different courses at the Faculty of Electrical Engineering and Computer Science were asked to fill in the questionnaire. Mostly these were courses from study program Informatics and also from the study program Media Communication and study program Computer Science

The questionnaire is organised in 6 sessions: Institution data, Information on students, students' preference on Project/Internship, Students selection criteria for Project/Internship, Students benefits on Project/Internship and Comments.

For data analysis we have used IBM SPSS Statistics 21 [2] [3]. Preliminary results of the survey are presented in frequency and descriptive statistics tables for specific parts of the survey [3].

\section{RESEARCH}

Research on Projects/Internships offered to students was carried out in Slovenia at the University of Maribor, Faculty of Electrical Engineering and Computer Science in 2013, from January until end of March. Preliminary results are presented. Finally, the survey included 216 students from the bachelor study programs of Faculty of Electrical Engineering and Computer Science. Students were taking part in following courses: Databases (2 different courses), Databases for Media, Databases and Modelling and Programing for Media.

\section{A. Demographics}

In Table 1 the descriptive statistics for demographics show analysis of age, gender, degree/level of the program and year of study in the program of students who filled in the survey. As seen in the table, the mean age of the students was 20.28 with s.d. of 2.03. All the students were in the bachelor level of the program.

TABLE I

DESCRIPTIVE STATISTICS FOR DEMOGRAPHICS

\begin{tabular}{|l|r|r|r|r|r|c|c|}
\hline \multicolumn{7}{|c|}{ Descriptive Statistics } & $\begin{array}{c}\text { Std. } \\
\text { Dev. }\end{array}$ \\
\hline & Stat. & Stat. & Stat. & Stat. & Stat. & $\begin{array}{c}\text { Std. } \\
\text { Error }\end{array}$ & Stat. \\
\cline { 2 - 7 } & Sange & Min. & Max & \multicolumn{2}{|c|}{ Mean } & 2,0302 \\
\hline $\begin{array}{l}\text { Age of the } \\
\text { student } \\
\text { full years) }\end{array}$ & 216 & 23,0 & 18,0 & 41,0 & 20,287 &, 1381 & \\
\hline
\end{tabular}




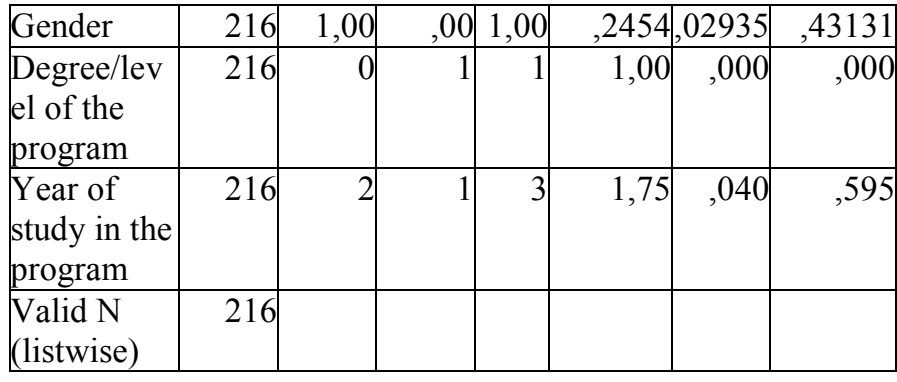

Taking into account that this is a technical faculty, 75.5\% of students were male as seen in Table 2. Most of female students were from Media Communication program.

TABLE II

GENDER

\begin{tabular}{|r|r|r|r|r|r|}
\hline \multicolumn{7}{|c|}{ Gender } \\
\hline \multicolumn{2}{|c|}{} & Freq. & Perc. & $\begin{array}{c}\text { Valid } \\
\text { Percent }\end{array}$ & $\begin{array}{c}\text { Cumulative } \\
\text { Percent }\end{array}$ \\
\hline \multirow{2}{*}{ Valid } & Male & 163 & 75,5 & 75,5 & 75,5 \\
\cline { 2 - 6 } & Female & 53 & 24,5 & 24,5 & 100,0 \\
\cline { 2 - 6 } & Total & 216 & 100,0 & 100,0 & \\
\hline
\end{tabular}

Students mostly stated that their area of study is Computing and IT $(n=208)$ as seen in Table 3. Most of the students, who filled the survey, were students of Informatics and Computer science and around 50 students were from Media Communication study program. It is interesting that also those students selected as a field of study Computing and IT. Seems that they misunderstood the question and make a decision on the base of the course in which they were completed questionnaire.

TABLE III

AREA OF STUDY

\begin{tabular}{|l|l|r|r|r|r|}
\hline \multicolumn{7}{|c|}{ Area of study } \\
\hline \multicolumn{1}{|c|}{} & Freq. & Perc. & $\begin{array}{c}\text { Valid } \\
\text { Percent }\end{array}$ & $\begin{array}{c}\text { Cumulative } \\
\text { Percent }\end{array}$ \\
\hline \multirow{5}{*}{ Valid } & $\begin{array}{l}\text { Computing and } \\
\text { IT }\end{array}$ & 208 & 96,3 & 96,3 & 96,3 \\
\cline { 2 - 6 } & $\begin{array}{l}\text { Education and } \\
\text { training }\end{array}$ & 1 &, 5 &, 5 & 96,8 \\
\cline { 2 - 6 } & Engineering & 5 & 2,3 & 2,3 & 99,1 \\
\cline { 2 - 6 } & Social Sciences & 1 &, 5 &, 5 & 99,5 \\
\cline { 2 - 6 } & Services & 1 &, 5 &, 5 & 100,0 \\
\cline { 2 - 6 } & Total & 216 & 100,0 & 100,0 & \\
\hline
\end{tabular}

Students were mostly in the 2 nd year of study $(n=127)$ as in Table 4.

TABLE IV

YeAR OF STUDY IN PROGRAM

\begin{tabular}{|r|r|r|r|r|r|}
\hline \multicolumn{7}{|c|}{ Year of study in the program } \\
\hline \multicolumn{2}{|c|}{} & Freq. & Perc. & $\begin{array}{c}\text { Valid } \\
\text { Percent }\end{array}$ & $\begin{array}{c}\text { Cumulative } \\
\text { Percent }\end{array}$ \\
\hline \multirow{3}{*}{ Valid } & 1st year & 71 & 32,9 & 32,9 & 32,9 \\
\cline { 2 - 6 } & 2nd year & 127 & 58,8 & 58,8 & 91,7 \\
\cline { 2 - 6 } & 3rd year & 18 & 8,3 & 8,3 & 100,0 \\
\hline
\end{tabular}

\begin{tabular}{|l|l|l|l|l|l|}
\hline & Total & 216 & 100,0 & 100,0 & \\
\hline
\end{tabular}

\section{B. Analysis of preferences regarding Projects/Internships}

In this section we have analysed the results from students about their view of Projects / Internships.

$67.1 \%$ of students would rather work in a team than as individuals (see Table 5). What we can estimate as a positive for their future work in companies.

TABLE V

ORGANIZATION OF THE WORK IN THE COURSE

\begin{tabular}{|r|r|r|r|r|r|}
\hline \multicolumn{6}{|c|}{ Organization of the Work in the Course } \\
\hline \multicolumn{2}{|c|}{} & Freq. & Perc. & $\begin{array}{c}\text { Valid } \\
\text { Percent }\end{array}$ & $\begin{array}{c}\text { Cumulative } \\
\text { Percent }\end{array}$ \\
\hline \multirow{3}{*}{ Valid } & individual & 71 & 32,9 & 32,9 & 32,9 \\
\cline { 2 - 6 } & team & 145 & 67,1 & 67,1 & 100,0 \\
\cline { 2 - 6 } & Total & 216 & 100,0 & 100,0 & \\
\hline
\end{tabular}

Table 6 presents preference of national or international teams. Students prefer national teams $(56.5 \%)$ to international teams (43.5\%). The preference to international teams is over $40 \%$, what is surprising in positive way. Namely the score of students in the Erasmus and other mobilities is much lower.

TABLE VI

NATIONAL OR INTERNATIONAL TEAMS

\begin{tabular}{|l|l|r|r|r|r|}
\hline \multicolumn{7}{|c|}{ If team - national or international? } \\
\hline \multirow{2}{*}{} & Freq. & Perc. & $\begin{array}{c}\text { Valid } \\
\text { Percent }\end{array}$ & $\begin{array}{c}\text { Cumulative } \\
\text { Percent }\end{array}$ \\
\hline \multirow{4}{*}{ Valid } & $\begin{array}{l}\text { national } \\
\text { (local) }\end{array}$ & 109 & 50,5 & 56,5 & 56,5 \\
\cline { 2 - 6 } & international & 84 & 38,9 & 43,5 & 100,0 \\
\cline { 2 - 6 } & Total & 193 & 89,4 & 100,0 & \\
\hline Missing & System & 23 & 10,6 & & \\
\hline Total & 216 & 100,0 & & \\
\hline
\end{tabular}

Table 7 presents that students would rather work in real teams $(94.3 \%)$ than in virtual teams.

TABLE VII

REAL OR VIRTUAL TEAMS

\begin{tabular}{|l|l|r|r|r|r|}
\hline \multicolumn{7}{|c|}{ If team - real or virtual? } \\
\hline \multirow{3}{*}{} & Freq. & Perc. & $\begin{array}{c}\text { Valid } \\
\text { Percent }\end{array}$ & $\begin{array}{c}\text { Cumulative } \\
\text { Percent }\end{array}$ \\
\hline \multirow{3}{*}{ Valid } & real team & 183 & 84,7 & 94,3 & 94,3 \\
\cline { 2 - 6 } & $\begin{array}{l}\text { virtual } \\
\text { team }\end{array}$ & 11 & 5,1 & 5,7 & 100,0 \\
\cline { 2 - 6 } & Total & 194 & 89,8 & 100,0 & \\
\hline Missing & System & 22 & 10,2 & & \\
\hline Total & 216 & 100,0 & & \\
\hline
\end{tabular}

Mostly students prefer working in groups of up to 8 persons $(95.9 \%)$, out of which $51.5 \%$ prefer teams with less than 4 persons and $44.3 \%$ prefer teams with $4-8$ persons. Also this we can estimate very positive, namely teams up to 4 people at least for Project/Internship are easy to master in the way that 
all members are contributing equally, while by bigger teams we can have some hidden not active members.

TABLE VIII

SIZE OF THE TEAM

\begin{tabular}{|l|l|r|r|r|r|}
\hline \multicolumn{7}{|c|}{ If team - size of the team? } \\
\hline \multirow{5}{*}{ Valid } & \multicolumn{1}{|c|}{ Freq. } & Perc. & $\begin{array}{l}\text { Valid } \\
\text { Perc. }\end{array}$ & $\begin{array}{c}\text { Cumulative } \\
\text { Percent }\end{array}$ \\
\hline & $\begin{array}{l}\text { small team } \\
\text { (less than 4) }\end{array}$ & 100 & 46,3 & 51,5 & 51,5 \\
\cline { 2 - 6 } & $\begin{array}{l}\text { medium team } \\
(4-8)\end{array}$ & 86 & 39,8 & 44,3 & 95,9 \\
\cline { 2 - 6 } & $\begin{array}{l}\text { large team } \\
\text { (over 8) }\end{array}$ & 8 & 3,7 & 4,1 & 100,0 \\
\cline { 2 - 7 } & Total & 194 & 89,8 & 100,0 & \\
\hline Missing & System & 22 & 10,2 & & \\
\hline Total & & 216 & 100,0 & & \\
\hline
\end{tabular}

As seen in Table 9, 61\% of students $(n=131)$ prefer home institution as the most appropriate place when they would be looking for Project/Internship. Abroad would be prepared to go 56 students, what is confirming the surprising result from the Tabel 6 . There were only 35 students $(16 \%)$ who would be looking for a Project/Internship in a virtual environment.

TABLE IX

PLACE OF WORK

\begin{tabular}{|l|r|r|r|r|r|r|r|}
\hline & N & Range & Min. & Max. & \multicolumn{2}{|c|}{ Mean } & \multicolumn{1}{|c|}{$\begin{array}{c}\text { Std. } \\
\text { Dev. }\end{array}$} \\
\cline { 2 - 8 } & Stat. & Stat. & Stat. & Stat. & Stat. & $\begin{array}{c}\text { Std. } \\
\text { Error }\end{array}$ & Statistic \\
\hline $\begin{array}{l}\text { Home } \\
\text { institution }\end{array}$ & 216 & 1 & 0 & 1 &, 61 &, 033 &, 490 \\
\hline $\begin{array}{l}\text { National } \\
\text { company }\end{array}$ & 216 & 1 & 0 & 1 &, 44 &, 034 &, 498 \\
\hline $\begin{array}{l}\text { Research } \\
\text { lab }\end{array}$ & 216 & 1 & 0 & 1 &, 41 &, 034 &, 493 \\
\hline Abroad & 216 & 1 & 0 & 1 &, 26 &, 030 &, 442 \\
\hline Virtual & 216 & 1 & 0 & 1 &, 16 &, 025 &, 369 \\
\hline $\begin{array}{l}\text { Valid N } \\
\text { (listwise) }\end{array}$ & 216 & & & & & & \\
\hline
\end{tabular}

Students mostly prefer project combined with internship $(46.3 \%)$ or only project $(43.1 \%)$ as an option (see Table 10$)$.

TABLE X

PROJECT / INTERNSHIP OPTION

\begin{tabular}{|c|c|c|c|c|c|}
\hline \multicolumn{6}{|c|}{ Project/Internship option } \\
\hline & & Freq. & Perc. & $\begin{array}{l}\text { Valid } \\
\text { Percent }\end{array}$ & $\begin{array}{c}\text { Cumulative } \\
\text { Percent }\end{array}$ \\
\hline \multirow{4}{*}{ Valid } & Project & 93 & 43,1 & 43,1 & 43,1 \\
\hline & Internship & 23 & 10,6 & 10,6 & 53,7 \\
\hline & $\begin{array}{l}\text { Project combined } \\
\text { with internship }\end{array}$ & 100 & 46,3 & 46,3 & 100,0 \\
\hline & Total & 216 & 100,0 & 100,0 & \\
\hline
\end{tabular}

Table 11 shows that students $(n=213)$ would mostly prefer duration between 1 and 3 months (44.1\%) and between 3 and 6 months $(29.1 \%)$ for a Project/Internship. Only $10.8 \%$ of students prefer longer duration for a Project/Internship. From experiences we can conclude, that most of students decided for $1-3$ month Project/Internship, would prefer 2 month Project/Internship.

TABLE XI

DURATION

\begin{tabular}{|c|c|c|c|c|c|}
\hline \multicolumn{6}{|c|}{ Duration } \\
\hline & & Freq. & Perc. & $\begin{array}{c}\text { Valid } \\
\text { Percent }\end{array}$ & $\begin{array}{c}\text { Cumulative } \\
\text { Percent }\end{array}$ \\
\hline \multirow{5}{*}{ Valid } & $\begin{array}{l}\text { less than } 1 \\
\text { month }\end{array}$ & 34 & 15,7 & 16,0 & 16,0 \\
\hline & $\begin{array}{l}1 \text { to } 3 \\
\text { months }\end{array}$ & 94 & 43,5 & 44,1 & 60,1 \\
\hline & $\begin{array}{l}3 \text { to } 6 \\
\text { months }\end{array}$ & 62 & 28,7 & 29,1 & 89,2 \\
\hline & $\begin{array}{l}\text { more than } 6 \\
\text { months }\end{array}$ & 23 & 10,6 & 10,8 & 100,0 \\
\hline & Total & 213 & 98,6 & 100,0 & \\
\hline Missing & System & 3 & 1,4 & & \\
\hline \multicolumn{2}{|l|}{ Total } & 216 & 100,0 & & \\
\hline
\end{tabular}

Students ( $n=209)$ have been given an option of full or part time mode (see Table 12). 56.9\% selected full time option and $43.1 \%$ part time.

TABLE XII

MODE

\begin{tabular}{|l|l|r|r|r|r|}
\hline \multicolumn{7}{|c|}{ Mode } \\
\hline \multirow{4}{*}{ Valid } & \multicolumn{1}{|c|}{ Freq. } & Percent & $\begin{array}{c}\text { Valid } \\
\text { Percent }\end{array}$ & $\begin{array}{c}\text { Cumulative } \\
\text { Percent }\end{array}$ \\
\cline { 2 - 6 } & \begin{tabular}{l} 
full \\
time \\
part \\
\cline { 2 - 6 }
\end{tabular} & 119 & 55,1 & 56,9 & 56,9 \\
\cline { 2 - 6 } & Total & 209 & 96,8 & 100,0 & 100,0 \\
\hline $\begin{array}{l}\text { Missin } \\
\text { g }\end{array}$ & System & 7 & 3,2 & & \\
\hline Total & & 216 & 100,0 & & \\
\hline
\end{tabular}

Students had to estimate, how relevant are specific characteristics for them when they are selecting Project/Internship on a 5-degree Likert scale (1-least important, 5-most important) [4],[5]. With a mean 4.21 the most important characteristic was 'Subject/topic' and the characteristic 'Chances to get a job upon conclusion of the PI course' had a mean 4.09. The least important characteristics were 'Brand' (mean=3.25) and 'Being abroad' (mean=3.24). Again we have to conclude that students are less interested for mobility as for other options. In the case of Slovenia survey we have to add in the future some sub questions to find out why all with internationalization connected questions are negative, except questions about international teams. 
TABLE XIII

The Most Relevant Characteristics For StUdents WHEN SELECTING THEIR PROJECT/INTERNSHIP

\begin{tabular}{|c|c|c|c|c|c|c|c|}
\hline \multicolumn{8}{|c|}{ Descriptive Statistics } \\
\hline & $\mathrm{N}$ & Range & $\mathrm{Mi}$ & Max. & \multicolumn{2}{|c|}{ Mean } & Std. \\
\hline & Stat. & Stat. & Stat & Stat. & Stat. & $\begin{array}{l}\text { Std. } \\
\text { Error }\end{array}$ & Stat. \\
\hline Company & 216 & 4 & 1 & 5 & 3,71 & ,061 & 895 \\
\hline Brand & 216 & 4 & 1 & 5 & 3,25 & ,063 & ,925 \\
\hline $\begin{array}{l}\text { Salary/scholars } \\
\text { hip }\end{array}$ & 216 & 4 & 1 & 5 & 3,99 &, 060 & ,884 \\
\hline Subject/topic & 216 & 4 & 1 & 5 & 4,21 &, 053 & ,782 \\
\hline Being abroad & 216 & 4 & 1 & 5 & 3,24 & ,071 & 1,036 \\
\hline $\begin{array}{l}\text { Working in a } \\
\text { team }\end{array}$ & 216 & 4 & 1 & 5 & 3,46 & ,076 & 1,120 \\
\hline $\begin{array}{l}\text { Chances to get } \\
\text { a job upon } \\
\text { conclusion of } \\
\text { the PI course }\end{array}$ & 216 & 4 & 1 & 5 & 4,09 & ,062 & ,908 \\
\hline $\begin{array}{l}\text { Valid N } \\
\text { (listwise) }\end{array}$ & 216 & & & & & & \\
\hline
\end{tabular}

$74 \%$ of students believe that the main benefits of Project/Internship will be 'Getting experience on a field of my own interest' and $71 \%$ of students believe they will benefit for a 'Chance to be employed by the company/institution offering the PI'. Over $50 \%$ is estimate also 'Working in a professional setting' and close to $50 \%$ is also 'Working on a real-world non-academic assignment'. As surprise we would estimate that now, less than $50 \%$ of students $(43 \%)$ are interested in team work, while other results showed more interest for this form of working. The smallest amount of students (9\%) believes they will gain 'Autonomy'. Also getting to know labour reality was estimate low independent to the benefit for future work and possibilities on labour market (see Table 14).

TABLE XIV

MAIN BENEFITS OF PROJECT/INTERNSHIP FOR STUDENTS

\begin{tabular}{|c|c|c|c|c|c|c|c|}
\hline \multicolumn{8}{|c|}{ Descriptive Statistics } \\
\hline & $\mathrm{N}$ & Rang & Min. & Max. & \multicolumn{2}{|c|}{ Mean } & Std. \\
\hline & Stat. & Stat. & Stat. & Stat. & Stat. & $\begin{array}{c}\text { Std. } \\
\text { Error }\end{array}$ & Stat. \\
\hline $\begin{array}{l}\text { Chance to be } \\
\text { employed by } \\
\text { the } \\
\text { company/inst } \\
\text { itution } \\
\text { offering the } \\
\text { PI }\end{array}$ & 216 & 1 & 0 & 1 & ,71 & ,031 & ,456 \\
\hline $\begin{array}{l}\text { Getting to } \\
\text { know labour } \\
\text { reality }\end{array}$ & 216 & 1 & 0 & 1 & ,38 & ,033 & ,488 \\
\hline $\begin{array}{l}\text { Working in a } \\
\text { professional } \\
\text { setting }\end{array}$ & 216 & 1 & 0 & 1 & ,58 & ,034 & ,495 \\
\hline $\begin{array}{l}\text { Working on a } \\
\text { real-world } \\
\text { non-academic } \\
\text { assignment }\end{array}$ & 216 & 1 & 0 & 1 & ,47 & ,034 & ,500 \\
\hline
\end{tabular}

\begin{tabular}{|l|r|r|r|r|r|r|r|}
\hline Autonomy & 216 & 1 & 0 & 1 &, 09 &, 020 &, 291 \\
\hline $\begin{array}{l}\text { Working in a } \\
\text { team }\end{array}$ & 216 & 1 & 0 & 1 &, 43 &, 034 &, 496 \\
\hline $\begin{array}{l}\text { Getting } \\
\text { experience on } \\
\text { a field of my } \\
\text { own interest }\end{array}$ & 216 & 1 & 0 & 1 &, 74 &, 030 &, 439 \\
\hline $\begin{array}{l}\text { Valid N } \\
\text { (listwise) }\end{array}$ & 216 & & & & & & \\
\hline
\end{tabular}

If we summarise the Table 14, both highest believes are expected, because students want practical experiences and are prepared to put more energy in Project/Internship courses as in any other course with a high expectation for practical experiences and more chances on labour market.

\section{CONCLUSIONS}

The presented survey and the analysis are shown the interest of students for Project/Internship at the Faculty of Electrical Engineering and Computer Science, University of Maribor in study area Computing and IT. Most of the results are expected. Some unexpected results were commented next to tables that present results.

We have to point out that more work is needed in internationalization towards mobility, while most of students would like to stay in home surrounding, even that they prefer international teams. This "staying at home" will probably make there possibility lower, later at the labour market.

Interesting would be also comparison to the master degree students, but for this we have to obtain more answers from those students. Also comparison with Spanish results could be interested on the base that for the booth countries we obtain high number of responses.

\section{ACKNOWLEDGMENT}

The work and the outcomes described in this paper are due to the PRAXIS - European Centre for Project/Internship Excellence consortium and to the dedication of all partners involved in it.

This work has been funded with support from the European Commission under grant 518811-LLP-1-2011-1-PTERASMUS-ENW. This publication reflects the views only of the author, and the Commission cannot be held responsible for any use which may be made of the information contained therein.

We wish to acknowledge Aida Kamišalić Latifić, Andrej Sevčnikar, Borut Zlatolas, Lija Emmelin Verneli and Marko Hölbl for their help in collecting the results for the survey that we analysed.

We thanks also to students who took time and collaborate in the survey.

\section{REFERENCES}

[1] Technical report of Praxis 2013, April 2013.

[2] SPSS software. Available: http://www-

01.ibm.com/software/analytics/spss/, May 21, 2013.

[3] Argyrous G., Statistics for research : with a guide to spss, 3rd ed. Thousand Oaks, CA: Sage Publications, 2011. 
[4] Likert R.., A Technique for the Measurement of Attitudes. Archives of Psychology 140: 1-55, 1932.

[5] Norman G., Likert scales levels of measurement and the "laws" of statistics. Advances in Health Science Education. Vol. 15(5) pp. 625632, 2010. 